\title{
Star Mobile Apps: An Android-Based Learning Media to Support Paperless Policy and the Merdeka Belajar Program Implementation
}

Tutik Wijayanti ${ }^{1, *}$ Ruhadi $^{2,}$ Khakim Asshidiqi Nur Hudaya ${ }^{3,}$ Dwi Hermawan ${ }^{4}$,

Melynda $^{5}$

\author{
${ }^{1,2,5}$ Faculty of Social Sciences, Universitas Negeri Semarang \\ ${ }^{3}$ Faculty of Engineering, Universitas Negeri Semarang \\ ${ }^{4}$ Public Relation of Universitas Negeri Semarang \\ *Corresponding author. Email: tutikwijayanti@mail.unnes.ac.id
}

\begin{abstract}
A quality education is a description of a developed, peaceful, and leads to constructive qualities society. The success of education is not only lies in the educators and students factors, but also the use of an appropriate learning media will has a major influence on the understanding of students. A technology Advancements provides benefits to all fields, as well as in the education field. The utilization of technological advancements in education can be used in developing learning media. The use of smart phone and internet is dominated by the younger generation. It can be utilized in fulfilling learning needs. To solve problems regarding the use of conventional learning media, an innovative idea is needed to solve through Star Mobile Apps. Star Mobile Apps is an Androidbased learning media innovation that supports the implementation of paperless policy and the implementation of the Merdeka Belajar Program. This application is able to make learning activities become more interesting and interested by students. In addition, by utilizing technological advancements, this application can reduce the need of paper usage so that the paperless policy can be implemented. By encouraging the implementation of paperless policy, Star Mobile Apps also supports an effort to improve the environment both in rural and urban areas. This research is a research and development (Research \& Development) through four development procedures in the form of preliminary studies, program design, program development, and dissemination. The results of the preliminary studies showed that respondents still felt difficult in developing Android-based learning media. Based on these problems, a learning media is then designed that can accommodate learning needs through the use of technology. Then the design was validated by experts to be tested. Based on the results of expert validation, an average of $89.33 \%$ was obtained from the validators. It was an indication that the developed media is categorized as very good category. Application user responses also showed that $15 \%$ positive and $85 \%$ very positive. Meanwhile, student learning outcomes show that through learning media Star Mobile Apps can improve learning outcomes with an average N Gain of 0.701 .
\end{abstract}

Keywords: Android, Learning Media Innovation, Merdeka Belajar, Paperless Policy, Star Mobile Apps.

\section{INTRODUCTION}

Education is a media to achieve happiness and prosperity for all humans wherever they live. Quality education becomes a reflection of an advanced, peaceful society, and leads to constructive characteristics. The development of the era has an impact on all aspects of life, including in the field of education, namely the use of learning media, learning materials, and ways of learning that experiences many changes. This change can be seen from the concept of education in Indonesia, which has used conventional concept. In 2019, the Indonesian Minister of Education and Culture, Nadiem Anwar Makarim, gave an idea about the 
concept of learning that follows the development of the era without losing the essence of learning called the Merdeka Belajar Program and the Kampus Merdeka. The concept of Merdeka Belajar of Nadiem Makarim is inspired by his desire to create a happy learning atmosphere without being burdened by achieving certain scores or values [10].

The Merdeka Belajar and the Kampus Merdeka Program are ideas that campuses, lecturers, and students have the freedom to carry out learning. This freedom means that every lecturer or student can innovate and the existence of freedom to learn independently and creatively can be implemented. The learning is not only limited to learning in the classroom which is the lecturer explains while the student only sits to listen, but also the lecturer provides space for students to develop cognitive, affective, and psychomotor abilities. In addition, learning can be carried out anywhere without limited space and time. For example it can be conducted outside the room and can use electronic media as a form of following the development of digitalization which is considered more effective.

The development of the world today has experienced a lot of digitization process where all things can be done through smartphones and the internet, just like there is no distance between one country and another. Almost all aspects of life are internet-based, for example buying a meal, not having to come to a restaurant, shopping, or not coming to a supermarket, to report that can be done through a device. The data from We Are Social (2020)[18] states that at least 175.4 million Indonesians are connected to the Internet, which means that it is $64 \%$ of the total population. It was dominated by young people between 16-24 years old.

According to the data from the Indonesian Internet Service Providers Association, the level of smartphone usage with an age range of 35-39 years old was ranked first in the range of 24 million people, then followed by 30-34 years old reaching 23.3 million people then followed by $20-24$ years old ( 22.3 million people), 40-44 years old (16.9 million people), 15-19 years old (12.5 million people), 45-49 years old (7.2 million people), 50 years old and over (1.5 million people) and 10-14 years old around 786 thousand people[6].

The development and advancement of technology should be utilized in the field of education, namely the use of instructional media as a form of implementation of the Merdeka Belajar Program. The learning will be successful when students can enjoy the learning process, so that the material to be conveyed can be well received by students. The use of instructional media will determine the success of learning, when an educator still puts forward the conventional approach in the learning, students have a tendency not to be interested in the material presented. Therefore, the utilization of science and technology development is expected to encourage more interactive learning so that it can make students feel interest.

Furthermore, the ending of utilizing the development of science and technology in the education environment is to reduce the need of paper usage, or it is well known as paperless policy. Paperless policy is an effort to limit and reduce paper production and use by utilizing information technology. This policy will affect the production of paper so that the number of trees felled will be limited and reduced. This policy can be applied, bearing in mind that many educational activities that should use paper can be transferred or substituted into soft files in a particular application. It can start from simple things like online presence to dominant uses namely assignments and files in education field.

Based on this background, the education world requires a breakthrough in the development of an Android-based learning media that is able to make the learning process to be more interactive and desirable by students as well as supporting nonpaper policies. This research will focus on efforts to find out the concepts and characteristics of "Star Mobile Apps" as an Android-based learning application that supports Paperless Policy and the implementation of the Merdeka Belajar Program, knowing the stages of developing "Star Mobile Apps" as an android-based learning application that supports Paperless Policy and the implementation of the Merdeka Belajar Program, and analyze the efficiency of the "Star Mobile Apps" use in supporting Paperless Policy and the implementation of the Merdeka Belajar Program.

\section{LITERATURE REVIEW 2.1.Innovative Learning Media}

The media comes from the Latin language, medius which means "middle", "intermediary", or "introduction". More specifically, the media is a way to convey a message. Understanding the media in the teaching and learning process tends to be interpreted as graphic tools, as well as electronically used to send messages to be processed and then rearranged in the form of visual and verbal information. Media is a teaching aid that functions properly if the media is able to provide a meaningful, memorable, and enjoyable learning experience. In simple way, the media is a tool that conveys or delivers teaching message[2]. 
Learning media is a tool used to help convey messages or materials. According to Hanafiah \& Suhana (2012: 59)[11], learning media are all forms of stimulants and tools provided by the teacher to encourage students to learn quickly, precisely, easily, correctly, and do not occur verbalism. In addition, Arief S. Sadiman (2009: 7)[1] explained that learning media is everything that can be used to deliver messages from the sender to the recipient, so that it can stimulate the thoughts, feelings, concerns, and interests of students so that the learning process takes place properly.

Based on some of the opinions, learning media is more specifically interpreted as a tool or media used by the teacher to convey learning material so that it is able to influence students' thoughts, memories, concerns, and feelings to be able to receive learning material easily. In this case, learning media can be categorized into two categories. According to Anderson (1987) quoted in Warsita (2008: 123)[17], the media are divided into two categories namely instructional aids and instructional media. Teaching aids and media used in conveying learning material can be in the form of photos, maps, films, posters, graphics, models of actual objects, and to the use of technology in clarifying learning material.

Generally, learning media has the benefit of providing a new atmosphere in the interaction of teachers and students to improve students' ability to receive material. Psychologically, learning media also have the benefit of motivating or being a breaking ice for students in the learning process. It has an impact on student activity in learning process.

Levie \& Lentsz (1982) quoted by Hujair AH. Sanaky (2009: 6)[5] suggests four functions of learning media, especially visual media, namely: Attention Function, Affective Function, Cognitive Function, and Compensatory Function. The four functions are defined as follows.

1. The function of visual media is the key, which is to attract and direct students' attention to the content of the material related to the visual meaning displayed or accompanying the text of the material in the lesson. Students have a tendency to get bored quickly with the subject that they are not enjoy with, so they will not pay attention to the subject. Therefore, visual media are projected to direct students' attention to focus on the learning material they will receive.

2. The affective function of visual media can be seen from the level of student enjoyment when studying or reading pictorial text. Images or visual symbols are able to bring up emotions and attitudes of students in learning. For example including social or racial issues.

3. The cognitive function of visual media is seen from visual images or images that are able to facilitate the achievement of goals in understanding and remembering the information or messages contained in the image. Students often find it easier to remember information or messages contained in pictures.

4. The compensatory function of instructional media can be seen from the results that visual media provides context for understanding text to help students who are weak in reading to organize information in text and recall it. In other words, this function accommodates students who are weak and slow in accepting and understanding the content of the lessons presented in text or verbally.

\subsection{The Use of Android-Based Learning Media}

Technology advancements affect all aspects of life, especially in learning in schools and campuses. During a pandemic like nowadays, teachers and students begin to act more cooperatively in using online learning media. However, before the covid19 pandemic happen, the learning process took place face-to-face between the teacher and students in the classroom or commonly known as conventional learning method. Conventional learning method is not effective and do not foster motivation to students, so they do not understand the material provided by the teacher. The success of learning is not only determined by the teacher and students, but the use of instructional media also contributes greatly.

The development of science and technology makes learning more effective, efficient, and interesting (Wijaya, 2008). Information and communication technology changes the location of learning from class to place anywhere and anytime. Thus, communication technology encourages evolution in the setting of place and time of study. The learning is no longer only takes place in school and in the classroom, but learning can occur anywhere as long as there are teaching materials and students feel comfortable with the situation. Students as the core of the teaching and learning process, it must be involved in all phases of learning and it is the duty of a teacher to make students more active and provide a dynamic and meaningful learning experience. The learning media created can utilize Android-based technology, namely mobile phones. So far we know that mobile phones are not only focused as a means of communication or entertainment, but also used as learning media. 
Android-based learning media is a new innovative that is very effective when it is applied in the learning process.

\subsection{Paperless Policy}

Paperless policy is an ideal form of the information age with the advantages of being time efficient, environmentally friendly, better documentation management, and an important step in the organization's image in the field of environment and its environmental responsibilities. In an environmental context, paperless is a real step towards reducing the use of trees for paper. This is based on the fact that nearly 4 billion trees worldwide are cut down every year for paper, which represents about 35 percent of all trees cut down. The purpose of paperless policy is to reduce paper usage, and it does not eliminate paper usage altogether. Paperless is not the same as being paper free. Humans in every activity are almost impossible to escape from the use of paper, including in educational activities. The function of paperless in Tiwari and Syah (2010: 177)[15] is to minimize the use of paper in the office as a very idle situation in the institutional management system. The advantages that can be achieved include easy data storage, saving time, fun, safe, efficient, easy access to the data to be achieved.

As a human behavior to reduce the use of paper, paperless serves to reduce paper production. Paperless policy as a policy of reducing the use of paper is expected to reduce paper consumption without reducing the effectiveness of work or study for students in tertiary institutions. The concern of universities in suppressing the use of this paper on the one hand is one of the efforts in preventing global warming and restoring the function of forests as the lungs of the world. Unnes Conservation Development Team (2010) in Maslihah (2014)[9] explained the paperless functions, namely providing efficiency, better documenting, supporting better decision making, more controlled management, improved organizational image, and cost aspects.

\subsection{Merdeka Belajar Program}

The Merdeka Belajar Program is a new innovative in the field of education proposed by the Minister of Education and Culture to provide space for schools, teachers, and students to develop their skills, creativity, and innovation in learning. The concept of Merdeka Belajar is that every unit of education, namely schools, teachers, and students have the right to freedom. Freedom has a meaning that it is free to innovate in learning independently, develop creativity in learning. The concept of
Merdeka Belajar that was initiated was not only focused on curriculum development, but also focused on giving innovation space to teachers and students, so that the learning is not monotonous. This concept must be accompanied by the concept of "teacher mobilization" in which schools provide space for innovation for teachers to make movements. The motivating teacher is expected to be able to take the cheap actions to give the best to the students. One form of independent learnings is academic freedom.

\section{RESEARCH METHOD}

This type of research is research and development (Research and Development) that produces products in the form of an Android-based learning media "Star Mobile Apps". Development research is a research method used to produce products and test the effectiveness of the product [16]. According to Gay (1990)[4], development research is an attempt to develop an effective product for school use, not to the test theory. Meanwhile, Borg and Gall (1983: 772)[3] defines development research as follows.

"Educational Research and development $(\mathrm{R} \& \mathrm{D})$ is a process used to develop and validate educational products. The steps of this process are usually referred to as the $R \& D$ cycle, which consists of studying research findings pertinent to the product to be developed, developing the products based on these findings, field testing it in the setting where it will be used eventually, and revising it to correct the deficiencies found in the filedtesting stage. In more rigorous programs of $\mathrm{R} \& \mathrm{D}$, this cycle is repeated until the field-test data indicate that the product meets its behaviorally defined objectives".

Seals and Richey (1994)[14] provide development research definitions as a form of systematic assessment of designing, developing, and evaluating programs which the learning process and products must meet the criteria of validity, practicality, and effectiveness. In addition to these indicators, Plomp (1999)[12] adds other criteria, namely "can add value".

Development research procedures or steps according to Sugiyono (2015: 298)[16] have ten stages, but in this study, the stages carried out only reached the sixth stage. Researchers pay more attention to stages one through six. This is done considering that this initial stage becomes the stand point for how the sustainability of research will proceed. Stages one to six form are the basis of how products in research and development can be tested 
on a broader scale. The stages of this research development can be briefly explained in three steps, namely the preliminary study stage, the development stage, and the validation stage. It can be seen in the following figure 1.

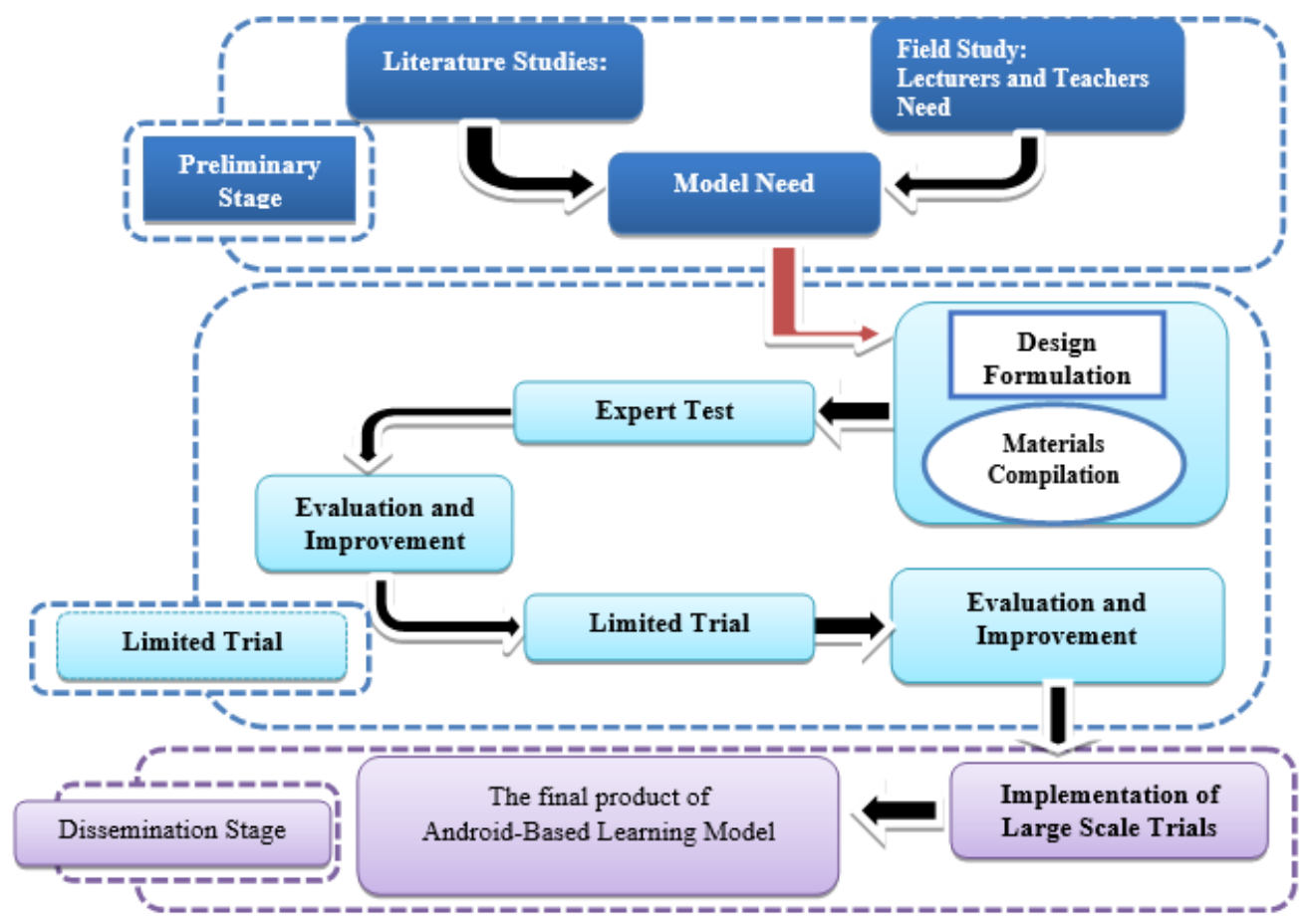

Figure 1. Flowchart of RnD Model Development

Source: Primary Data Processed, Sugiyono (2015: 297)

In the preliminary study stage, researchers conducted a literature study and field study. Field studies were conducted to identify the needs of educators (lecturers and teachers) regarding the learning process in the classroom. Then the researcher continues with the development stage. In this second stage, the researcher formulates the design (manufacture of instruments) and the collection of materials in order to arrange products that will be the outcome of the research. This output is based on the results of the identification of needs in the previous stage. This product design output places five indicators as the basis for making product designs. This indicator includes the display (user interface), the completeness of the features available, ease of access, program stability, and novelty of the application. After that, the instrument validation test will be continued by experts to get feedback as a basis for evaluating and improving output products. The validity of the instrument being measured is content validity and arrangement validity. This content validity is carried out by professional experts (expert judgment) and education evaluation experts / validators (judment). The next step is to conduct a limited trial. A limited trial was conducted on 20 students of the Faculty of Social Sciences in the Research Methods subject.

\section{RESULTS AND DISCUSSION}

This research is a Research and Development research that aims to develop android-based learning media as an implementation of Merdeka Belajar and efforts to support paperless policy. Media developed in the form of applications on Android-based smartphones. The application developed is Star Mobile Apps. This application is an innovative learning media to implement Merdeka Belajar that has been designed by the government.

\subsection{Concept and Characteristic of Star Mobile Apps}

Star Mobile Apps is an innovative learning media that has attractive designs, features, and characteristics. This application can be an alternative in supporting the learning process. Star Mobile Apps has four main features, namely material features, discussion features, assessment/ quiz features, and live learning features via video calls. In addition, Star Mobile Apps also has five characteristics that make it an attractive learning application. Star Mobile Apps has special characteristics namely (1) Star Mobile Apps based on Android; (2) Star Mobile Apps has complete features in supporting learning activities; (3) Star Mobile Apps strives to maintain service quality; (4) 
Star Mobile Apps is interactive, secure and has high accuracy; and (5) Star Mobile Apps has a wellorganized management system.

\subsection{Development Stages of "Star Mobile Apps"}

The development carried out in this research includes the preliminary study stage, the development stage, as well as the testing, and validation stages in accordance with the development research according to [16]. In the preliminary study stage, the initial step taken is to identify problems related to learning media innovation to implement independent learning. Reetu Malhotraa, et al. (2019)[8] explains "to facilitate information exchange by using the accessible technologies and to make it more userfriendly in the best possible ways" (to facilitate the exchange of information by using accessible technology and making it more friendly for user).

Based on the results of interviews conducted with respondents, the data obtained that so far the learning media innovation is considered very important in order to realize the Merdeka Belajar in the campus environment and support paperless policies. In the concept of Merdeka Belajar, the implementation of learning does not have to be carried out in the classroom, but can also be outside the classroom. Educators and students are given the freedom to innovate. By carrying out learning outside the classroom, it will minimize the use of paper that supports paperless policy. This freedom in innovation was also expressed by Izza et al. (2020)[7] which states that educators and students are given the freedom to innovate and learn independently and creatively.

Based on the results of the initial identification, it is obtained that the respondents have still had difficulty in learning fun and are supported by contemporary media. From the preliminary data obtained, the researchers then designed the development of an Android-based learning media as an effort to implement independent learning. This development was carried out by making a prototype of an Android-based learning media. From this prototype, it was further developed by designing and making it in the features that exist in the android application. The features developed consist of material features, discussion features, assessment/ quiz features and live learning features through video calls. The design that has been made is then validated by experts. The results of the validation of experts can be seen in table 1 .

Table 1. The Results of Expert Validation Average Score

\begin{tabular}{lcccl}
\hline \multicolumn{1}{c}{ Product Design } & \multicolumn{2}{c}{ Validator Score } & Average & Information \\
& 1 & 2 & & \\
\hline Display & $80 \%$ & $93,3 \%$ & $86,7 \%$ & Very Good \\
Available Features Completeness & $93,3 \%$ & $93,3 \%$ & $93,3 \%$ & Very Good \\
Ease of Access & $93,3 \%$ & $93,3 \%$ & $93,3 \%$ & Very Good \\
Program Stability & $80 \%$ & $86,7 \%$ & $83,35 \%$ & Very Good \\
Application Innovation & $93,3 \%$ & $86,7 \%$ & $90 \%$ & Very Good \\
Total Average & & & $89,33 \%$ & Very Good \\
\hline
\end{tabular}

Source: Primary Data Processed, 2020

Based on the above table, it can be seen that the results of the expert validation show that the learning media developed are very good, so that they can be continued for field trials. In general, the description of the learning media developed (Star Mobile Apps) consists of four components. These components are material features, discussion features, assessment/ quiz features and live learning features through video calls. Star Mobile Apps can be an alternative in developing distance learning. The utilization of the Star Mobile App can be a new innovation that combines simplicity of appearance (minimalism) and technological sophistication. Star Mobile Apps makes it easy for users to chat with other users, both personally and through groups (see figure 2).
Providing an online forum as shown in Figure 2 will allow interaction between students and other students and between students and lecturers in real time. This feature can be used by students to plan work assignments or discuss lecture topics with lecturers. The principle of developing Star Mobile Apps is to provide convenience for users, in this case is for students and lecturers. The existence of lecturers and students in the same forum in one subject will facilitate lecturers in providing feed in the form of lecture material. This application supports the integration of various files to be shared with group members (see figure 3 ). This file can be extended as.doc / .docx / other (supports standard formats from word processing devices), .xls / .xlsx / other (supports standard formats from number processing devices), .ppt / .pptx / other (supports 
standard formats from presentation processing devices), audio formats, video formats, and so on.

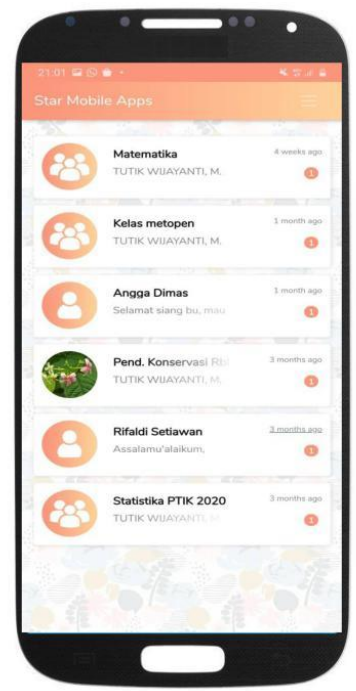

Figure 2. Message Appearance (Personal Message and Group)

Source: Researcher Illustration, 2020

In addition to support the file integration process, Star Mobile Apps is also equipped with other features that encourage more interactive teaching and learning activities. As a platform that offers novelty in the development of instructional media, Star Mobile Apps allows periodic Quiz schedules (can also function as a substitute for Midterm Exams). This feature allows the lecturer to give a number of questions which can be multiple choice, short entries, essays, or other forms according to the development and learning needs (see figure 4). This quiz feature also allows lecturers to add pictures as an introduction to questions. The work output by students can be known after the quiz is completed. By combining mathematical algorithms and a simple user interface display, quizzes are designed to increase students' learning enthusiasm so that they are encouraged to take part in subsequent learning.
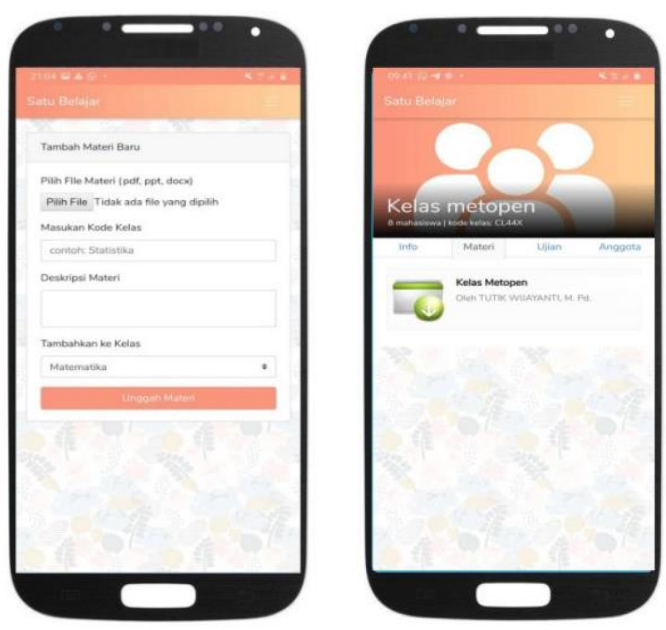

Figure 3. Display of Subject Material Input Process Source: Researcher Illustration, 2020

It is different with several standard learning media platforms, the Star Mobile App is designed with additional features in the form of transmitting moving images in real time or the ability to make video calls. This feature complements learning needs in connecting lecturers and students at the same time (see figure 4). Video call in the Star Mobile App is very compatible to be accessed through various types of Operation Systems (OS), both Android, iOS, and Harmony.

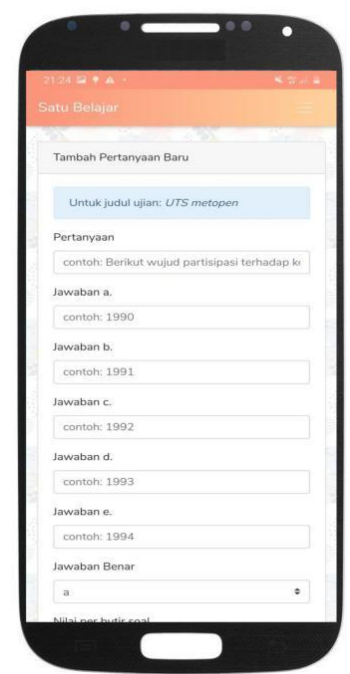

Figure 4. Display of Lecture Quiz Input Process Source: Researchers Illustration, 2020

In the framework of supporting a safe and comfortable learning process, going forward, Star Mobile Apps will also be developed by providing video encryption in it. This is important to maintain the comfort and security of user data during the learning process. Another advantage possessed by 
Star Mobile Apps is its ability to compress and reduce data usage, so users can set video call in data saver mode if it is needed.

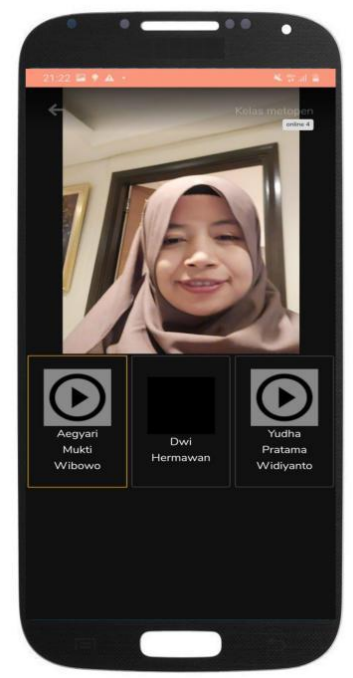

Figure 5. Display of Video Call Proses Source: Researchers Illustration, 2020

Learning media in the form of Star Mobile Apps that has been developed subsequently are tested on a limited scale. Field trials are conducted on several students and also on lecturers to see the user's response to the practicality of learning media

\subsection{Response of The Use of Star Mobile Apps}

The use of Star Mobile Apps is an alternative in organizing learning activities. This learning media functions to present educators (teachers) virtually for students. In addition, this application is also able to provide new learning experiences for students. Star Mobile Apps has attractive designs, features, and characteristics. The main features in Star Mobile Apps namely personal messages between users, messages in groups, input of learning materials, procurement of quizzes, and video calls make Star Mobile Apps an efficient application in learning. This is because in one application, users can use various features simultaneously. In addition, this efficiency is also evident from the characteristics possessed by Star Mobile Apps. These characteristics include: (1) Star Mobile Apps based on Android; (2) Star Mobile Apps has complete features in supporting learning activities; (3) Star Mobile Apps strives to maintain service quality, (4) Star Mobile Apps is interactive, secure, and has high accuracy; and (5) Star Mobile Apps has a well-organized management system.

After a limited trial, Star Mobile Apps received many positive responses from its users. Based on the test results obtained user response data as in table 2.

Table 2. User Response Recapitulation Application

\begin{tabular}{llcccc}
\hline \multirow{2}{*}{ No. } & \multirow{2}{*}{ Respondent } & \multicolumn{5}{c}{ Respondents Response To Developed Media } \\
& & Not Positive (\%) & Less Positive (\%) & Positif (\%) & Very Positif (\%) \\
\hline 1 & Lecturer & - & - & 20 & 80 \\
2 & Student & - & - & 10 & 90 \\
& Average & - & - & 15 & 85 \\
\hline
\end{tabular}

Source: Primary Data Processed, 2020

In table 2, it can be seen that based on the results of the trial use of the product, the user's response when on average $15 \%$ respond positively and $85 \%$ respond very positively. It means that the user's response can be said to be good, so the product developed meets one of the effective and efficient standards. In addition to looking at the user's response, to see how effective and efficient the media are, a trial application is used on a limited scale. This media is said to be effective in its use if it can improve student learning outcomes

The way to see the learning outcomes of students has reached a significant improvement or not, it is done by giving a pre-test at the beginning before given learning with Star Mobile Apps learning media and doing a post test after learning.
In this trial, it was practiced on 20 students in the Research Methods course. The next step is to analyze the results of the pretest and post test. Based on the results of the analysis by looking at the $\mathrm{N}$ Gain, the results obtained as in table 3. 
Table 3. Recapitulation of Student Learning Outcomes

\begin{tabular}{ccc}
\hline \multicolumn{2}{c}{$\begin{array}{c}\text { Learning Outcomes Average of Students by Using the Star Mobile Apps } \\
\text { Learning Media }\end{array}$} \\
Pre-test & Post Test & N Gain (\%) \\
\hline 70,56 & 91,20 & 0,701 \\
\hline
\end{tabular}

Source: Primary Data Processed, 2020

Referring to the table 3 above, Star Mobile Apps learning media can improve student learning outcomes with an average N Gain of 0.701. It means that Star Mobile Apps learning media has effectiveness and efficiency in improving student learning outcomes. Thus, it can be concluded that the learning media developed responded positively by the user and can improve student learning outcomes, so it makes it feasible to be used.

\section{CONCLUSION}

Star Mobile Apps as a learning media innovation that has an attractive design, features and characteristics. This application can be an alternative in supporting the learning process. Star Mobile Apps has four main features, namely the material feature, the discussion feature, the assessment / quiz feature and the live learning feature via video call. Star Mobile Apps is an alternative in organizing learning activities. It serves to present educators (teachers) virtually for students. The application development is carried out in stages, including the preliminary study stage, the development stage, and the trial and validation stages. Star Mobile Apps learning media can improve student learning outcomes with an average $\mathrm{N}$ Gain of 0.701. This means that the Star Mobile Apps has effectiveness and efficiency in improving student learning outcomes. Star Mobile App as an implementation of the Merdeka Belajar Program, which encourages the paperless policy.

\section{ACKNOWLEDGMENT}

The author would like to say thanks to the reviewer for the comments and valuable input provided in the writing of this article. The author also thanks to the experts who validated the instruments in this study.

\section{REFERENCES}

[1] Arief, S., 2009. Media pendidikan, pengertian, pengembangan, dan pemanfaatannya. Jakarta: PT. Rajagrafindo Persada.

[2] Arsyad, A., 2013. Media pembelajaran edisi revisi. Jakarta: Rajawali Pers.
[3] Brog, Walter R, and Gall Meredith D, 1983. Educational Research: An Introduction (3th ed.). New York: Longman

[4] Gay, L.R. 1990. Educational Evaluation and Measurement: Com-petencies for Analysis and Application. Second edition. New York: Macmillan Publishing Company.

[5] Hujair AH. Sanaky. 2009. Media Pembelajaran. Yogyakarta, Satria Insania Press.

[6] Indonesia, A.P.J.I., 2017. Infografis Penetrasi dan Perilaku Pengguna Internet Indonesia. ID: APJII.

[7] Izza, A.Z., Falah, M. and Susilawati, S., 2020. Studi Literatur: Problematika Evaluasi Pembelajaran dalam Mencapai Tujuan Pendidikan di Era Merdeka Belajar. Konferensi Ilmiah Pendidikan 2020, 1(1), pp.10-15.

[8] Malhotra, R., Kumar, D. and Gupta, D.P., 2020. An Android Application for Campus Information System. Procedia Computer Science, 172, pp.863-868.

[9] Maslihah, M. (2014). Kearifan Lingkungan Melalui Upaya Paperless Berbasis Teknologi Informasi Dan Komunikasi Bagi Mahasiswa Sekolah Tinggi Agama Islam Negeri (STAIN) Salatiga.

[10] Mustaghfiroh, S., 2020. Konsep "Merdeka Belajar" Perspektif Aliran Progresivisme John Dewey. Jurnal Studi Guru Dan Pembelajaran, 3(1), pp.141-147.

[11] Nanang Hanafiah and Cucu Suhana. 2012. Konsep Strategi Pembelajaran. Bandung: PT Refika Aditama.

[12] Plomp, T. 1999. Educational Design: Introduction. From Tjeerd Pomp (eds). Educational \& Training System Design: Introduction. Design of Education and Training (in Dutch). Utrecht (the Netherlands): Lemma. Netherland. Faculty of Educational Science and Technology, University of Twente 
[13] Sanjaya, W., 2006. Pembelajaran dalam implementasi kurikulum berbasis kompetensi. Kencana.

[14] Seels, B.B. and Richey, R.C., 1994. Teknologi pembelajaran: Definisi dan kawasannya. Penerjemah Dewi $S$. Prawiradilaga dkk. Jakarta: Kerjasama IPTPI LPTK UNJ.

[15] Shah, S. and Tiwari, M., 2010. Networking of Paperless Offices in Technical Institutes of India. IJCSNS, 10(3), p.177.

[16] Sugiyono, P., 2015. Metode penelitian kombinasi (mixed methods). Bandung: Alfabeta.

[17] Warsita, B., 2008. Teknologi pembelajaran landasan dan aplikasinya. Jakarta: Rineka Cipta, 135.

[18] We Are Social. 2020. Digital 2020 Indonesia: All the Data, Trends, and Insights You Need to Help You Understand How People Use the Internet, Mobile, Social Media, and Ecommerce 